\title{
Influence of Organic Manures on Quality Parameters like Crude Protein Content (\%), Statistical Analysis and Economics in Wheat (Triticum aestivum L.)
}

\author{
Ch. Sivanagalakshmi ${ }^{1}$, Dr. Narendra Singh ${ }^{2}$, Gajendra Singh $^{1}$, \\ Ankush Singh ${ }^{1}$ and Pragya Rawat ${ }^{3}$
}

\author{
${ }^{1}$ Department of Agronomy, ${ }^{2}$ Department of Veterinary Sciences, ${ }^{3}$ Department of \\ Biotechnology, Alpine Institute of Technology, Premnagar, Dehradun (U.K), India
}

*Corresponding author

Keywords

Organic manures,

Vermicompost and farmyard manure,

Poultry manure and

Enriched compost

Article Info

Accepted:

24 July 2020

Available Online:

10 August 2020

\section{A B S T R A C T}

Interest in soil enzyme activity has increased recently since their activities are believed to reflect the potential capacity of soil to perform nutrient transformations. Since, soil microbial and enzyme systems are associated with organic manure management, incorporation of organic manures into soil not only plays an important role in soil chemical and biological activity, but also affects the rate at which nutrients become available to crop plants as well as other forms of life. The Present experiment consisted of nine treatments $\mathrm{T}_{1}: \mathrm{RDF}, \mathrm{T}_{2}$ : EC (1/4) basal + PM (3/4) basal, T $:$ FYM (1/4) basal + VC (3/4) basal, T $:$ FYM (1/4) basal + PM (3/4) basal, $\mathrm{T}_{5}$ : EC (1/4) basal + VC (3/4) basal, $\mathrm{T}_{6}: \mathrm{FYM} \mathrm{(1/4)} \mathrm{basal} \mathrm{+}$ PM (3/4) top dressing 30DAS, T : EC (1/4) basal + VC (3/4) top dressing @ 30 DAS, T 8 : EC (1/4) basal + PM (3/4) top dressing at 30DAS, $\mathrm{T}_{9}$ : Control. The study revealed that, among the treatments $\mathrm{T}_{8}$ : EC (1/4) basal + PM (3/4) top dressing at 30DAS has the highest crude protein content (13.30\%), low cost of cultivation $(25,570.00 \mathrm{Rs} / \mathrm{ha})$, high gross returns per hectare $(62,387.00 \mathrm{Rs} / \mathrm{ha})$, high net returns per hectare $(36817.00 \mathrm{Rs} / \mathrm{ha})$ and benefit cost ratio B:C (2.43) compared to control.

\section{Introduction}

Wheat (Triticum aestivum) is one of the most widely grown crops in the world, and is the second most important source of staple food in India after rice. In order to increase the wheat yield the farmers are extensively using the chemical fertilizer for higher yield. During the era of green revolution the farmers stressed more in use hybrid and high yielding varieties. Response of maize-wheat cropping sequence to phosphorus and farm yard manure (Negi et al., 1988). However it increased the crop production and productivity but supplying the nutrient source from inorganic fertilizer for long term without 
any addition of organic manures affected the soil health and resulted in the large scale deficiency of micro nutrients in soil which play an important role in enhancing the quality and quantity of the agriculture production.

Further, heavy application of inorganic fertilizer left residues in grain fruits and vegetables and caused human and animal health. The use of inorganic fertilizer alone also reduces the fertilizer use efficiency by crop through creation of problems such as volatilization, leaching and denitrification of nitrogen, to overcome the problem of nutrient deficiency and helping the nature rather than destroying it (Singh et al., 2001).

Organic sources of nutrients are the best option maintain the health of soil, plant and animal and provide the equal opportunity for all living existence to live and use from their beneficial activities, like nitrogen fixation, phosphorus solubilization, recycling of animal waste etc. Hence, the present study was undertaken. To overcome the problem of nutrient deficiency and to increase wheat yield, the farmers are applying chemical fertilizers. However, the chemical fertilizers are expensive and the small farmers cannot afford to use these fertilizers in suitable amount and balanced proportion. Under such condition integrated use of chemical and organic fertilizer/manures can play an important role to sustain soil fertility and crop productivity (Khadtare et al., 2006). Influence of vermicompost on quality parameters and soil fertility status of sweet corn (Zeamays L. saccharata). The use of organics largely excludes the use of synthetic fertilizers, pesticides, growth regulators and livestock feed additives, enriches the soil, encourages bio-diversity, reduce the toxic bodies (Auti et al., 1999). Improves water quality, creates a safe environment for people and wild life, produces nutritious food of high quality, supply micronutrients in soil and maintains soil fertility and crop productivity.

\section{Materials and Methods}

\section{Seed source}

For the present study, seeds of wheat variety PBW-550 were obtained from Dept. of agriculture Dehradun, Uttarkhand.

\section{Description of variety}

The wheat variety PBW 550 is a yellow rust resistant version of PBW 550. Its average plant height is $86 \mathrm{~cm}$ and matures in about 145 days. Its average grain yield is 23.0 quintals per acre. It is resistant to yellow and brown rusts and susceptible to loose smut.

\section{Design and layout}

The experiment will be laid out in a Randomized block design (RBD) with three replications (Fig. 1). The experimental details and lay out plan are given below:

Crop : Wheat (Triticum aestivum L.).

Variety : PBW-550

Spacing : $22.5 \mathrm{~cm} \times 10 \mathrm{~cm}$

Design : Randomized block design (RBD)

Replications : 03

Total treatments : 09

Gross plot : $2.5 \mathrm{~m} \times 1.5 \mathrm{~m}$

Irrigation channel $: 0.5 \mathrm{~m}$

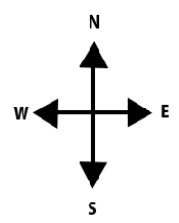

\section{Treatment details}

$\mathrm{T}_{1}-\mathrm{RDF}$

$\mathrm{T}_{2}$ - EC (1/4) basal + PM (3/4) basal

$\mathrm{T}_{3}$ - FYM (1/4) basal + VC (3/4) basal

$\mathrm{T}_{4}-\mathrm{FYM}(1 / 4)$ basal + PM (3/4) basal

$\mathrm{T}_{5}-\mathrm{EC}(1 / 4)$ basal + VC (3/4) basal

$\mathrm{T}_{6}-\mathrm{FYM}$ (1/4) basal + PM (3/4) top dressing 30DAS

$\mathrm{T}_{7}$ - EC (1/4) basal + VC (3/4) top dressing @ 


\section{DAS}

$\mathrm{T}_{8}$-EC (1/4) basal + PM (3/4) top dressing at 30DAS

$\mathrm{T}_{9}$ - Control

Note 1: All organics are made equivalent to recommended dose of nitrogen (RDN)

Note 2: FYM: Farm yard manure, VC: Vermicompost, PM: Poultry manure, EC: Enriched compost

Note 3: RDF (recommended dose of fertilizers 100:75:50 kg NPK ha' ${ }^{-1}$.

\section{Sowing of seed}

The seeds of wheat were sown in the field on $16^{\text {th }}$ November 2018.

The seeds were sown directly into the plots made on main field. Sowing was done in row spaced $22.5 \mathrm{~cm}$ later seeds were covered manually. Soon after sowing the plots were irrigated and then regular irrigations were applied at an interval of 10 days.

\section{Harvesting and threshing}

Crop was harvested on $10^{\text {th }}$ April 2018 after attaining physiological maturity. The harvested crop was dried in the sun and weighed before threshing. Each plot was threshed separately as per treatment and the weight of grains per plot was recorded in $\mathrm{kg}$.

\section{Quality parameters}

\section{Crude protein content (\%)}

The individual treatment wise grain samples were subjected to nitrogen content analysis by modified Micro kjeldhal method (Piper, 1966). Then the protein content analysis by modified treatment was calculated by multiplying the nitrogen content (\%) in the grain by the factor 5.7 (Tai and Young, 1974). It was expressed in per cent.

\section{Statistical analysis}

Fisher's method of analysis of variance as given by Gomez and Gomez (1984) was applied for analysis and interpretation of data. The level of significance used in F test was at $\mathrm{p}=0.05$. critical difference $(\mathrm{CD})$ was worked out whenever ' $F$ ' test was significant.

Correlation studies were made between yield and yield attributing characters, growth parameters, quality parameters, uptake of nutrients as per procedure outlined by Gomez and Gomez (1984).

\section{Economics}

Based on the current price of input used and produce obtained during 2018, the net profit per hectare ad benefit cost $(\mathrm{B}: \mathrm{C})$ ratio was worked out by using the following formula.

Net profit $\left(\mathrm{Rs} \mathrm{ha}^{-1}\right)=$ Gross income $\left(\mathrm{RS} \mathrm{ha}^{-1}\right)$ cost of cultivation $\left(\mathrm{Rs} \mathrm{ha}^{-1}\right)$

Benefit cost ratio $=$

$$
\frac{\text { Gross income }\left(\mathrm{Rs} \mathrm{ha}^{-1}\right)}{\text { Cost of cultivation }\left(\mathrm{Rs} \mathrm{ha}^{-1}\right)}
$$

\section{Results and Discussion}

The results of experiment conducted to study the effect of organic manures on growth, yield and grain quality of wheat (Triticum aestivum L.) during Rabi season 2018-2019 are presented in this paper.

\section{Quality parameter}

Crude protein content (\%) (Table 1 and Fig. 2)

$\mathrm{T}_{8}$ - EC (1/4) basal + PM (3/4) top dressing @ 30 DAS significantly showed higher protein 
$(13.30 \%)$ content than all other treatments and was followed by $\mathrm{T}_{6^{-}}$FYM (1/4) basal + PM (3/4) top dressing @ 30 DAS (12.91\%)which was on par with $\mathrm{T}_{2}$ - EC (1/4) basal $+\mathrm{PM}$ (3/4) basal(12.70\%). The lowest $(11.70 \%)$ was recorded in $\mathrm{T}_{9}$ - Control.

Table.1 Grain protein content as influenced by organic manures

\begin{tabular}{|c|c|}
\hline Treatments Protein content & \\
\hline $\mathrm{T}_{1}-\mathrm{RDF}$ & 12.383 \\
\hline$T_{2}$ - EC (1/4) basal + PM (3/4) basal & 12.707 \\
\hline$T_{3}$ - FYM (1/4) basal + VC (3/4) basal & 11.817 \\
\hline$T_{4}$ - FYM (1/4) basal + PM (3/4) basal & 12.193 \\
\hline$T_{5}-\mathrm{EC}(1 / 4)$ basal + VC (3/4) basal & 12.040 \\
\hline 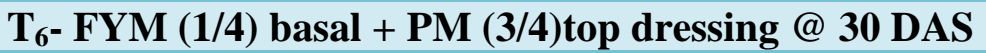 & 12.910 \\
\hline$T_{7}-$ EC (1/4) basal + VC (3/4) top dressing @ 30 DAS & 12.117 \\
\hline T8- EC (1/4) basal + PM (3/4) top dressing @ 30 DAS & 13.300 \\
\hline$T_{9}-$ Control & 11.700 \\
\hline $\mathrm{CD}(\mathrm{p}=\mathbf{0 . 0 5})$ & 0.116 \\
\hline C.V. & 0.542 \\
\hline S.Em \pm & 0.400 \\
\hline
\end{tabular}

Table.2 Cost of cultivation, gross returns, net returns and benefit cost ratio (B:C) as influenced by organic manures

\begin{tabular}{|c|c|c|c|c|}
\hline Treatments & $\begin{array}{c}\text { Cost of } \\
\text { cultivation } \\
\left(\text { Rs.ha }^{-1}\right)\end{array}$ & $\begin{array}{c}\text { Gross } \\
\text { returns } \\
\left(\text { Rs.ha }^{-1}\right)\end{array}$ & $\begin{array}{c}\text { Net } \\
\text { returns } \\
\left(\text { Rs.ha-1 }^{-1}\right)\end{array}$ & B:C \\
\hline $\mathrm{T}_{1}-\mathrm{RDF}$ & $24,306.67$ & $51,321.33$ & 20014.66 & 2.11 \\
\hline $\mathrm{T}_{2}-\mathrm{EC}(1 / 4)$ basal + PM (3/4) basal & $25,570.00$ & $57,496.67$ & 31926.67 & 2.24 \\
\hline $\mathrm{T}_{3^{-}}$FYM (1/4) basal + VC (3/4) basal & $36,500.33$ & 50000.00 & 13499.00 & 1.36 \\
\hline $\mathrm{T}_{4^{-}}$FYM (1/4) basal + PM (3/4) basal & $32,233.33$ & $52,236.33$ & 20003.33 & 1.62 \\
\hline$T_{5^{-}} \mathrm{EC}(1 / 4)$ basal + VC (3/4) basal & $32,233.33$ & $50,075.67$ & 17842.34 & 1.55 \\
\hline $\begin{array}{l}\text { T6- FYM (1/4) basal + PM (3/4)top } \\
\text { dressing @ 30 DAS }\end{array}$ & $24,306.67$ & 58376.67 & 34070.00 & 2.40 \\
\hline $\begin{array}{l}\text { T}_{7^{-}} \text {EC (1/4) basal + VC (3/4) top } \\
\text { dressing @ } 30 \text { DAS }\end{array}$ & $36,500.00$ & $52,000.33$ & 14821.33 & 1.42 \\
\hline $\begin{array}{l}\text { T- EC (1/4) basal + PM (3/4) top } \\
\text { dressing @ 30 DAS }\end{array}$ & $25,570.00$ & $62,387.00$ & 36817.00 & 2.43 \\
\hline$T_{9}-$ Control & $13,700.00$ & $32,735.33$ & 19035.00 & 2.38 \\
\hline $\mathrm{CD}(\mathrm{p}=\mathbf{0 . 0 5})$ & -- & 144.97 & 144.97 & -- \\
\hline C.V. & -- & 0.18 & 0.18 & --- \\
\hline S.Em \pm & --- & 67.80 & 67.80 & --- \\
\hline
\end{tabular}


Fig.1 Plan layout of the experimental site

R-I

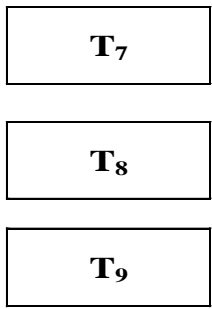

$\mathbf{T}_{6}$

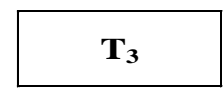

$\mathbf{T}_{4}$

$\mathbf{T}_{\mathbf{5}}$

$\mathbf{T}_{2}$

$\mathbf{T}_{1}$
R-II
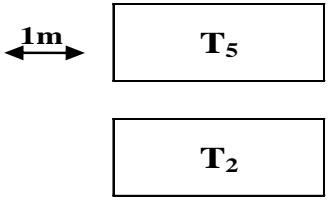

$\mathbf{T}_{3}$

$\mathbf{T}_{4}$

$\mathbf{T}_{\mathbf{1}}$
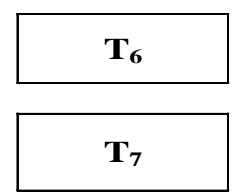

$\mathbf{T}_{\mathbf{8}}$

$\mathbf{T}_{9}$
R-III

$\stackrel{1 \mathrm{~m}}{\longrightarrow}$

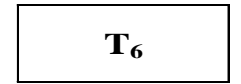

$\mathbf{T}_{9}$

$\mathbf{T}_{8}$

$\mathbf{T}_{7}$

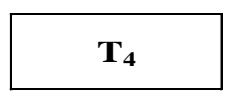

$\mathbf{T}_{5}$

$\mathbf{T}_{2}$

$\mathbf{T}_{1}$

$\mathbf{T}_{3}$

Fig.2 Grain protein content as influenced by organic manures

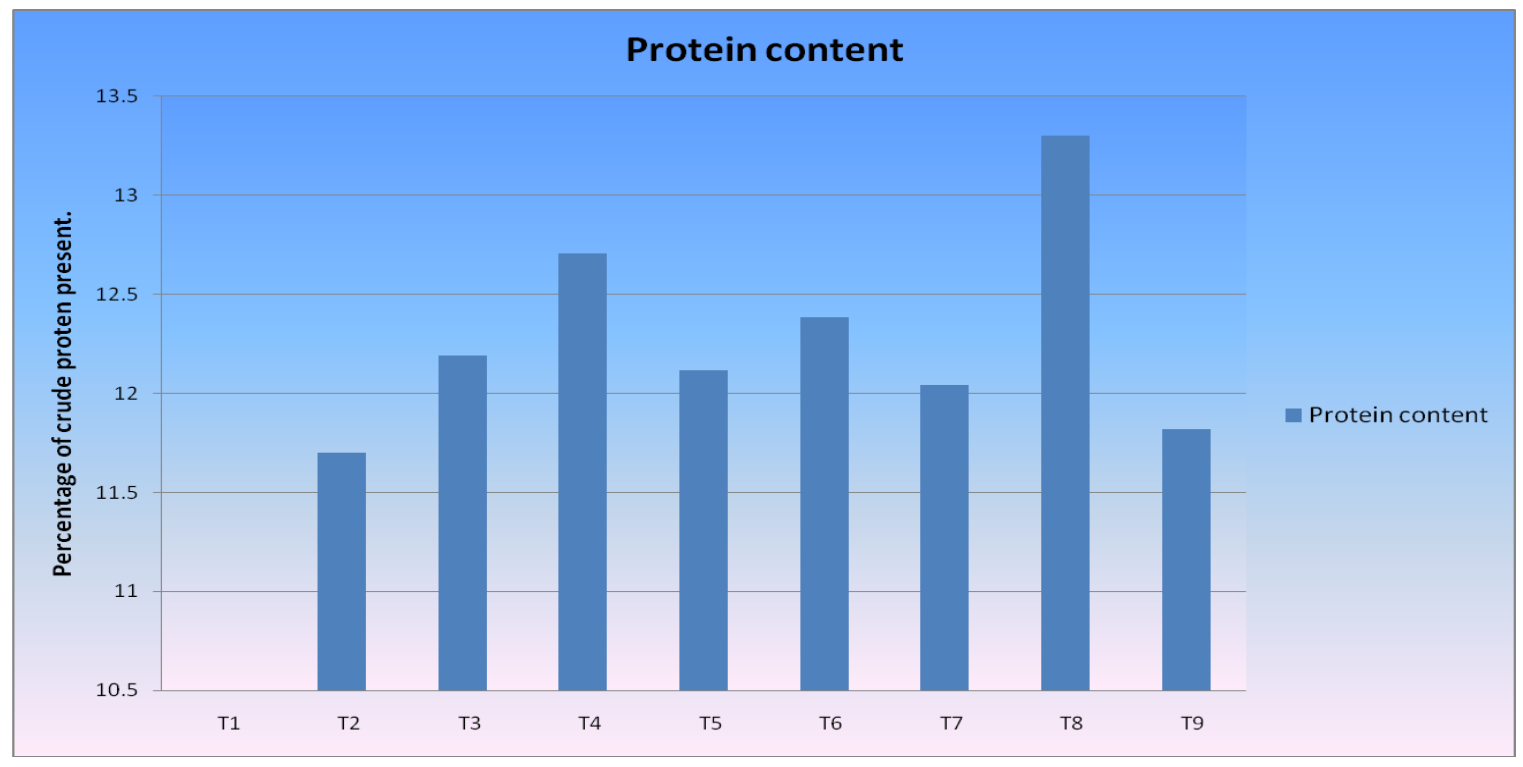


Fig.3 Grain yield, straw yield, harvest index and 1000 grain weight (g) as influenced by organic manures

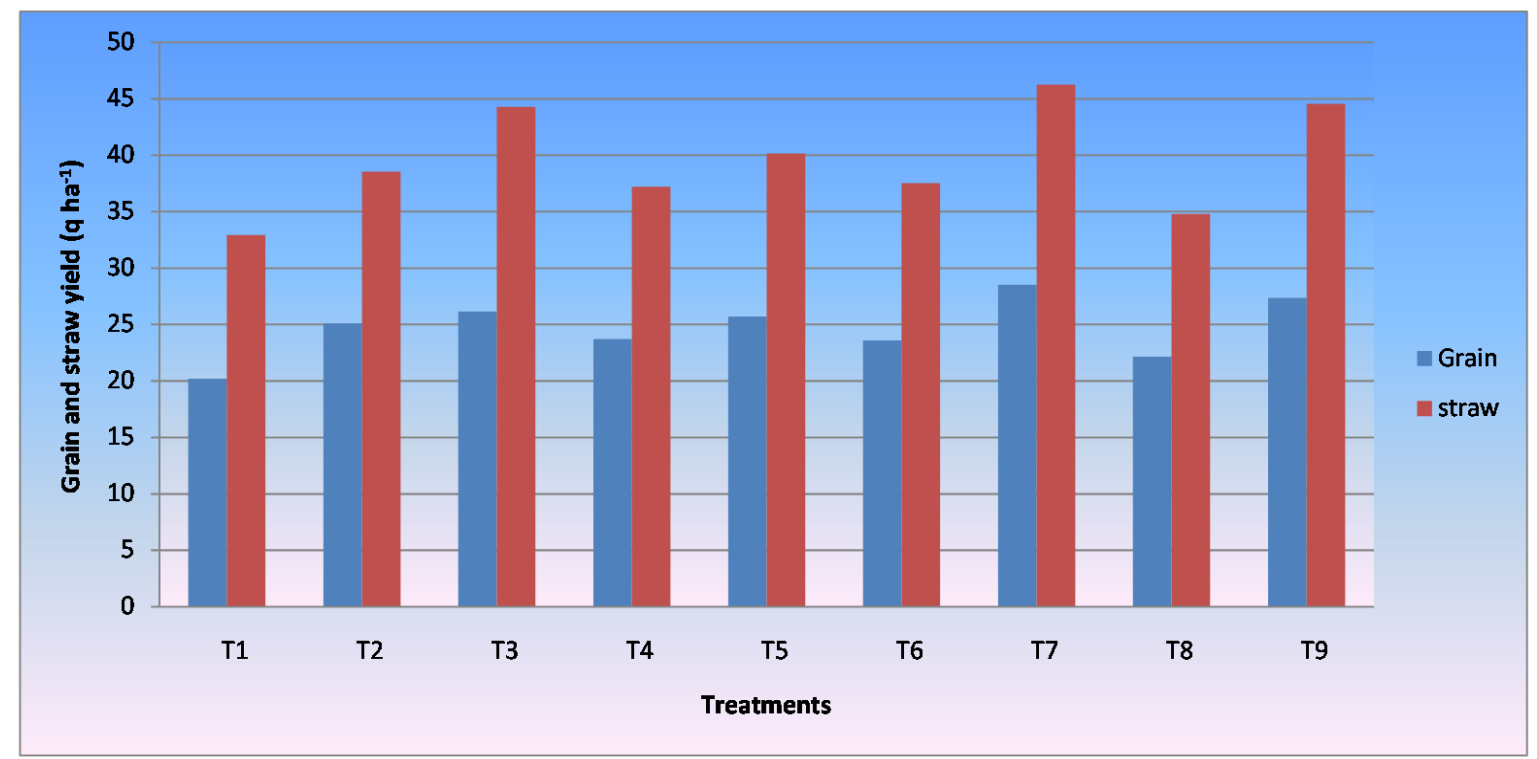

\section{Economics}

\section{Cost of cultivation $\left(\operatorname{Rs~ha}^{-1}\right)$}

The data pertaining significant changes in cost of cultivation ( $\mathrm{Rs} \mathrm{ha}^{-1}$ ) in treatments are presented in Table 2 and Fig. 3.

Maximum cost of cultivation (Rs 36500) was recorded in $\mathrm{T}_{3}-\mathrm{FYM}(1 / 4)$ basal $+\mathrm{VC}(3 / 4)$ basal and $\mathrm{T}_{5}-\mathrm{EC}(1 / 4)$ basal $+\mathrm{VC}(3 / 4)$ basal (Rs 32233) while the minimum cost of cultivation was recorded in $\mathrm{T}_{9^{-}}$Control (Rs 13700).

\section{Gross returns ( $\left.\operatorname{Rs~ha}^{-1}\right)$}

The data pertaining significant changes in gross returns $\left(\mathrm{Rs} \mathrm{ha} \mathrm{ha}^{-1}\right)$ in treatments are presented in Table 2 and Fig. 3.

Maximum gross returns (Rs 62387) was recorded in $\mathrm{T}_{8^{-}}$EC (1/4) basal + PM (3/4) top dressing @ 30 DAS followed by $\mathrm{T}_{6}-\mathrm{FYM}$ (1/4) basal + PM (3/4)top dressing @ 30 DAS (Rs 58376) further $\mathrm{T}_{2}$ - EC (1/4) basal + PM (3/4) basal (Rs 57496) and the minimum gross return was recorded in $\mathrm{T}_{9^{-}}$Control ( $\mathrm{Rs}$ 32735).

\section{Net returns (Rs. ha $\left.{ }^{-1}\right)$}

The data pertaining significant changes in Net returns (Rs. ha ${ }^{-1}$ ) in treatments are presented in Table 2 and Fig. 3.

Maximum net returns (Rs 36817) was recorded in $\mathrm{T}_{8^{-}}$EC (1/4) basal + PM (3/4) top dressing@30 DAS, followed by $\mathrm{T}_{6}$ - FYM (1/4) basal + PM (3/4) top dressing @ 30 DAS (Rs 34070) while the minimum net return was recorded in $\mathrm{T}_{3}$ - FYM (1/4) basal + VC (3/4) basal (Rs 13499).

\section{Benefit cost ratio (B:C) (Table No.2)}

The data pertaining significant changes in Benefit cost ratio (B:C)in treatments are presented in Table 2 and Fig. 3. The highest $\mathrm{B}: \mathrm{C}(2.43)$ was recorded in $\mathrm{T}_{8}$ - EC (1/4) basal + PM (3/4) top dressing @ 30 DAS, followed by $\mathrm{T}_{6^{-}}$FYM (1/4) basal + PM (3/4) top dressing @ 30 DAS (2.40) and it was on par with $\mathrm{T}_{2}$ - EC (1/4) basal + PM (3/4) basal 
(2.24). The lowest benefit cost ratio (1.13) was recorded in $\mathrm{T}_{3}$ - FYM (1/4) basal + VC (3/4) basal (1.36).

It is concluded that, $\mathrm{T}_{8}$ - EC (1/4) basal + PM (3/4) top dressing @ 30 DAS significantly showed higher protein $(13.30 \%)$ content than all other treatments and the lowest $(11.70 \%)$ was recorded in $\mathrm{T}_{9^{-}}$Control. The statistical analysis showed that gross and net returns of wheat were significantly higher in case of $\mathrm{T}_{8^{-}}$ EC (1/4) basal + PM (3/4) top dressing @ 30 DAS (Rs 62387 and $36817 \mathrm{ha}^{-1}$ ) While the minimum gross and net returns was recorded in $\mathrm{T}_{9^{-}}$Control (Rs 32735 and 19035 respectively $\mathrm{ha}^{-1}$ ). Significantly higher $\mathrm{B}: \mathrm{C}$ was recorded with $\mathrm{T}_{8^{-}}$EC (1/4) basal + PM (3/4) top dressing @30 DAS (2.43) and the minimum B:C (1.36) was recorded inT $_{3}$ FYM (1/4) basal+ VC (3/4) basal.

Almost all the growth and yield attributing characters were particularly correlated with the grain yield. To achieve maximum yield of wheat during Rabi season under irrigation, an organic nutrient management system involving combinations FYM, Enriched compost and Poultry manure helps in maximizing the grain and straw yield of wheat as well as with higher returns.

Under organic production system, integrated organic nutrient management practices involving application of EC (1/4) basal + PM (3/4) top dressing @ 30 DAS resulted in higher net returns over other organic manure combinations. For sustaining the crop productivity, application of EC (1/4) basal + PM (3/4) top dressing @ 30 DAS is recommended.

\section{References}

Gomez, K. A. and Gomez, A. A., (1984). Statistical Procedures for Agri. Res, John Willy, New York, 2 pp. 693.

Gomez, K.A. and Gomez, A., (1976). Statistical procedures for Agricultural Research (2/E). John Willey and Sons, New York.

Khadtare, S. V., Patel, M. V., Mokashi, D. D. and Jadhav, J. D., (2006). Influence of vermicompost on quality parameters and soil fertility status of sweet corn (Zea mays L. saccharata). J. Soils Crops, 16(2): 384-389.

Piper, C. S., (1966). Soil and Plant Analysis, Academic Press, New York, pp. 47-77.

Auti, A.K., Wadile, S.C. and Pawar, V.S. Yield, quality and nutrient removal of wheat (Triticum aestivum L.) as influenced by levels and sources of fertilizer. Indian J. Agron., 1999. 44(1): 119-120.

Negi, S.C, Singh, K.K. and Thakur, R.C., Response of maize-wheat cropping sequence to phosphorus and farm yard manure. Indian J. Agron. 1988. 33(3): 270-273.

Singh, G. R., Chaure, N. K. and Prihar, S. S., Effect of poultry manure and chemical fertilizer on summer sesame. Indian Farming. 2001. 51(3): 13.

\section{How to cite this article:}

Sivanagalakshmi, Ch., Narendra Singh, Gajendra Singh, Ankush Singh and Pragya Rawat. 2020. Influence of Organic Manures on Quality Parameters like Crude Protein Content (\%), Statistical Analysis and Economics in Wheat (Triticum aestivum L.). Int.J.Curr.Microbiol.App.Sci. 9(08): 3220-3226. doi: https://doi.org/10.20546/ijcmas.2020.908.367 